\title{
Does the commodities boom support the export led growth hypothesis? Evidence from Latin American countries
}

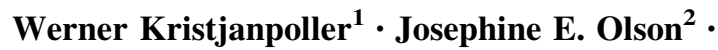 \\ Rodolfo I. Salazar ${ }^{1}$
}

Received: 9 August 2014/Revised: 19 September 2016/Accepted: 6 October 2016/

Published online: 20 October 2016

(C) The Author(s) 2016. This article is published with open access at Springerlink.com

\begin{abstract}
Commodity prices are characterized by boom and bust cycles. In this article, the impact of the commodity boom of the 2000s on Latin American and Caribbean economies is studied by analyzing four categories of commodity exports (agricultural raw materials, fuel, food, ore and minerals) as well as manufactured exports. Latin American and Caribbean economies had higher growth during the 2000s than in the period before the commodities boom. This study examines whether the higher growth was explained by the commodity boom, and if so, which of the different export commodities accounted for this higher growth. The findings should be relevant to understanding the effects on economic growth of a possible bust in commodity prices. The results show that ore and mineral exports, fuel exports and food exports generally had a negative effect on GDP per capita growth but ore and mineral exports had a positive effect on LAC countries during the boom. During the boom period, agricultural exports had negative effects, especially for LAC countries. Fuel exports had a positive effect on LAC and non-LAC countries during the boom. Manufacturing exports in general had a positive effect on economic growth, but in the boom period this effect almost disappeared for the LAC countries.
\end{abstract}

Keywords Economic growth - Latin American and Caribbean · Commodity boom · Export led growth

JEL Classification F43 $\cdot$ F44 $\cdot$ O11

Werner Kristjanpoller werner.kristjanpoller@usm.cl

1 Universidad Tecnica Federico Santa Maria, Valparaiso, Chile

2 University of Pittsburgh, Pittsburgh, Pennsylvania, United States 


\section{Introduction}

Growth of real gross domestic product (GDP) is generally considered to be beneficial for a country and a sign of a well-managed economy. GDP per capita is also a widely used parameter to measure a country's standard of living. Thus, an analysis of the most relevant determinants of economic growth is useful. Earlier studies have tried to determine the variables that impact economic growth, such as labor productivity changes, changes in exports and changes in the capital stock. Other studies have incorporated government policies to measure their effect on GDP growth. This study adds to the literature by examining the impact of exports during the commodity boom of the first decade of the twenty first century on the growth of Latin American and Caribbean (LAC) countries.

The case of LAC countries has become more interesting since the Nineties when many of their economies were liberalized (Dijkstra 2000) in terms of more favorable rules for foreign direct investment, lower tariffs and non-tariff barriers to trade, and regional trade agreements. In recent years, LAC countries have also had higher average growth rates than in earlier years. In the period 2000-2010 the average yearly real GDP per capita growth of LAC countries was $2.56 \%$, whereas during the 1990-1999 decade the average yearly growth was only $2.07 \%$. For all the nonLAC countries in our study, the difference in average growth rate in the two decades, 2.72 versus $2.19 \%$, was slightly greater. The increased growth rates that took place during the commodity boom period are large, and therefore, it is important to understand the origins and causes of this change.

Since the majority of LAC countries are important commodity exporters, the question in this study is whether or not their increased growth is related to the commodities boom of the 2000s. To answer this question we measure how much of GDP per capita growth can be assigned to the boom using a panel data analysis applied to LAC and non-LAC countries. The study includes neoclassical growth model variables such as capital formation and growth of labor, export growth and, following studies such as Sprout and Weaver (1993) and Arora and Vamvakidis (2005a), trade partner growth. We then add variables for the commodity boom and specific exports to see if they better explain growth. The conclusions that result from this paper are important because they help to determine whether these above average growth rates are sustainable in the longer term, and if they are important for policy makers, government authorities and trade agreement negotiators, among others, to take into consideration in their decisions. Since commodity booms are often followed by commodity busts, as demonstrated by Spatafora and Tytell (2009), it is important to estimate the relationship between the growth rates of LAC economies and the commodity boom. By understanding this, it may be possible to predict the impact of a commodity bust on future LAC growth rates.

The 2000s commodities boom is indicated by the IMF's commodity price indices. In Fig. 1, the trend in the prices of the principal commodities can be seen for the period 1990-2010. The Metals Price Index rose $275 \%$ in the boom period (2000-2010), while the average of the three Crude Oil Price Indices increased $261 \%$ and the Agricultural Raw Materials Index rose $50 \%$ in the same period. The 


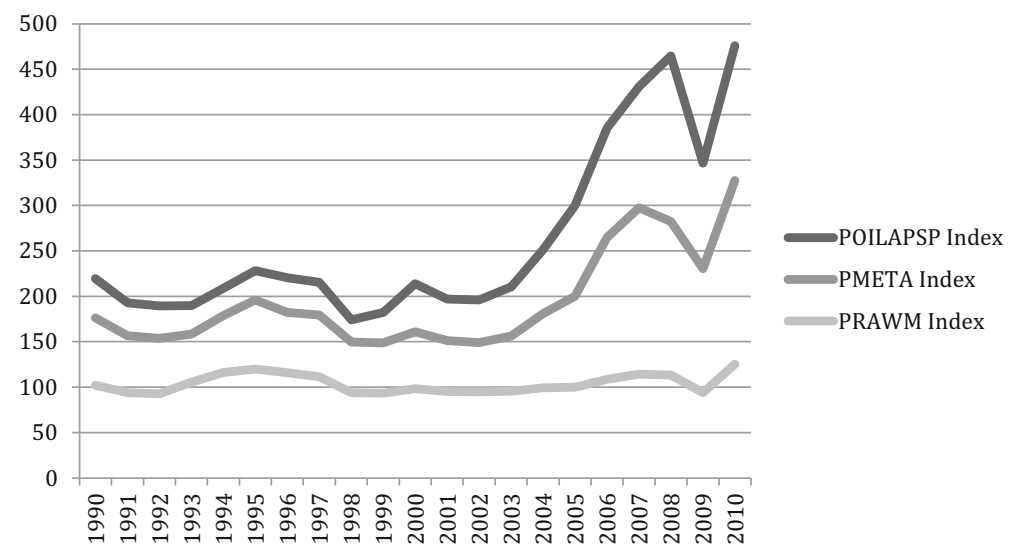

Fig. 1 Price evolution of the main commodity indexes 1990-2010. PRAWM Agricultural Raw Materials Index, $2005=100$, includes timber, cotton, wool, rubber, and hides price indices; PMETA Metals Price Index, $2005=100$, includes copper, aluminum, iron ore, tin, nickel, zinc, lead, and uranium price indices; POILAPSP Crude Oil (petroleum) Price index, $2005=100$, simple average of three spot prices

three indices dropped between 2008 and 2009, but by 2010 they had completely recovered. Humphreys (2010) stated that this commodity boom was the longest one since the Second World War.

This paper is organized as follows. Section 2 presents a review of studies that examine why economies grow and the critical variables in this process. Section 3 presents the hypothesis and methodology used in this paper and the data sources and their characteristics. Section 4 presents the results of the models. Concluding remarks are presented in the final section.

\section{Literature review}

The study of economic growth has attracted the attention of economists since the beginning of economic science. Since it is hard to isolate specific causes due to the dynamic nature of economies, many explanations for the phenomenon of growth have arisen; some of them have been proven to be empirically correct and others have had contradictory results. This section reviews export led growth (ELG) studies based on aggregate exports and then reviews studies based on specific types of exports, particularly commodities, and studies specific to LAC countries.

Export led growth (ELG) models explain economic growth as resulting from exports due to many factors such as economies of scale due to larger markets, concentration in industries where a country has a comparative advantage, technological improvements, the transmission of better management techniques, and more opportunities for entrepreneurial activities (Feder 1982; Giles and Williams 2000a; Kali et al. 2007; Dreger and Herzer 2013). An early ELG model is that of Feder (1982). In his empirical analysis, he estimated neoclassical models where growth of GDP was a function growth of capital and labor and ELG models 
that also included growth of aggregate real exports; the ELG models explained more of the growth than the neoclassical models. Although Feder did not include it in his models, other authors (e.g., Barro 1991; Sachs and Warner 1995; Greenaway et al. 1999) estimating GDP growth have argued that countries with lower initial levels of income per capita tend to growth faster in the short run, thus tending to converge to the GDP per capita levels of higher income countries.

Some more recent ELG studies have expanded on the role of exports in explaining growth of GDP. For example, Sprout and Weaver (1993) hypothesized that a country's export growth depended in part on the economic growth of its main trading partners. Arora and Vamvakidis (2005a) found that a $1 \%$ increase in a country's trade partners was correlated with as much as a $0.8 \%$ increase in its own growth. Other studies that have looked at some measure of trade partners' effect on a country's growth include Arora and Vamvakidis (2005b), Kali et al. (2007), Beny and Cook (2009), Fagiolo et al. (2010) and Dabla-Norris et al. (2015).

Hundreds of studies have now been conducted testing various versions of the ELG model with mixed results. Several studies have tried to evaluate the overall findings of ELG research. Giles and Williams (2000a, b) surveyed 150 ELG papers and were generally negative about the robustness of the studies. Two more recent studies have used meta-analysis to evaluate ELG studies and have more positive findings. Mookerjee (2006) examined 76 ELG studies; he found overall that exports were significantly correlated with growth. Sannassee et al. (2014) used metaanalysis on 82 ELG studies. Most of these studies showed that exports led to an increase in growth. They concluded that use of a production function approach with labor, capital and exports was the most appropriate model.

In addition to ELG studies that examine the effect of some measure of aggregate exports on exports, there are studies that have looked at the effect on growth of specific types of exports, particularly commodities. Mookerjee's (2006) meta-analysis examined not only aggregate exports but manufactured and oil exports, and found that use of these measures of exports tended to strengthen the relationship with GDP growth. Since we were not able to find surveys of these studies other than Mookerjee, we cite a few examples. Greenaway et al. (1999) estimated growth for all exports and then for different categories of exports; they found exports of fuels, metals and textiles had more effect on growth than food or other primary products. Al-Marhubi (2000) found that share of manufactured goods and more diverse exports increased growth. Beny and Cook (2009) looked at agricultural, ore and minerals, and petroleum exports (as a percentage of GDP) with an interaction effect for African countries. They found that agricultural exports, and to a lesser extent, ore and minerals had a positive effect on growth in Africa. Spatafora and Tytell (2009) looked at the effect of countryspecific commodity price cycles on more than 150 countries beginning in the early 1970s and found that median annual growth was nearly two percentage points higher during commodity price booms than busts. Collier and Goderis (2012) found an increase in commodity prices tended to have a short-run positive effect on growth, but the long-run effect was often negative, particularly for non-agricultural commodities and when the country was subject to bad governance. (Cavalcanti et al. 2015) examined the relationship between economic growth and an index of commodity terms of trade for 118 countries. They found that an improvement in the commodity 
terms of trade increased output but the volatility of the terms of trade had a negative effect on the primary product exporters. Addison et al. (2016) found that agricultural price shocks were positively correlated with growth in Sub-Saharan Africa.

A few recent studies have looked at Latin American growth and commodity prices. Siliverstovs and Herzer (2006) found that Chile's manufactured products had a positive impact on growth, whereas its primary exports did not. Camacho and Perez-Quiros (2014) related output growth to commodity price shocks in seven LAC countries and found that commodity price shocks were pro-cyclical. Gruss (2014) looked at the effect of the commodity boom on LAC countries and concluded there was a positive relationship between the growth in commodity prices and output growth in these countries; however, there was not a relationship between the level of prices and output growth.

\section{Hypothesis, data and methodology}

Given the good performance of LAC economies during the first decade of the twenty first century and the fact that many of these countries have export-oriented economies based on commodities, this study examines the effects of commodity exports on countries' per capita economic growth rates from 1990 to 2010 and during the commodity boom from 2000 to 2010 using a panel data analysis. First, we apply a chow breakpoint test to the three commodity price series shown in Fig. 1 to confirm 2000-2010 as the boom period. The results, shown in "Appendix", reject the null hypothesis for the three series, supporting the definition of the boom period as 2000-2010.

Next, we develop three estimation models centered on the literature review. The models are based on the relationship between the economic growth and measures of export composition, following Al-Marhubi (2000). The first model contains only the classical variables of the ELG model and trade partner growth. The second model includes interaction variables for the boom period and for the LAC countries during the boom. Third, we estimate five equations where we include individually each of the four commodity exports and manufactured exports, with interactions for the boom and the boom in LAC countries. The base model is shown in Eq. 1 and is similar to Al-Marhubi (2000).

$$
y_{i t}=\alpha+\sum_{k=1}^{n} \beta_{k} x_{k i t}+\sum_{j=1}^{m} \gamma_{j} z_{j i t}+\varepsilon_{i t},
$$

where $y_{i t}$ is the GDP per capita growth for country $i$ in year $t, x_{k i t}$ is the control variables $k$ for country $i$ in year $t$ and $z_{j i t}$ is the $j$ export variables. The control variables are the initial level of GDP per capita in each country $\left(Y_{i 0}\right)$; labor $\left(1_{i t}\right)$ and capital $\left(k_{i t}\right)$ (following the neoclassical growth model); and aggregate exports $\left(a x_{i t}\right)$ and a weighted average growth of country $i$ 's trade partners $\left(t p_{i t}\right)$. As a proxy for the 
natural logarithm of labor, we utilize the hypothesis that hours worked are stationary around a time trend, as in DeJong and Whiteman (1991), Dreger and Herzer (2013), and Leybourne (1995). Thus, in this model, the effect of labor is incorporated as a constant $\beta_{1}$. Then the model can be written as Eq. 2 .

$$
y_{i t}=\alpha+\beta_{0} Y_{i 0}+\beta_{1}+\beta_{2} k_{i t}+\beta_{3} a x_{i t}+\beta_{4} t p_{i t}+\sum_{k=-1}^{1} \gamma_{k} z_{i t}+\varepsilon_{i t},
$$

where $\beta_{0}$ is a negative parameter and the other $\beta$ 's are positive parameters.

As exports may have an endogeneity problem with the dependent variable, the lead and lag differences of export growth are added to the equation, so their coefficients $\gamma_{k}$ account for serial correlation and endogeneity (Herzer and Vollmer 2012).

Our second model includes the impact of the boom period on all countries in our study and on the LAC countries, and is shown in Eq. 3.

$$
\begin{aligned}
y_{i t}= & \alpha+\beta_{0} Y_{i, o}+\beta_{1}+\beta_{2} k_{i t}+\beta_{3} a x_{i t}+\beta_{4} t p_{i t}+\beta_{5} \text { Boom } D_{t}+\beta_{6} \operatorname{Lac} D_{i} \cdot \operatorname{Boom} D_{t} \\
& +\left(\beta_{7} k_{i t}+\beta_{8} x_{i t}+\beta_{9} t p_{i t}\right) \cdot \operatorname{Boom} D_{t}+\left(\beta_{10} k_{i t}+\beta_{11} x_{i t}+\beta_{12} t p_{i t}\right) \\
& \times \operatorname{Lac} D_{i} \cdot \operatorname{Boom} D_{t}+\sum_{k=-1}^{1} \gamma_{k} \Delta x_{i t}+\varepsilon_{i t} .
\end{aligned}
$$

Boom $D_{t}$ is a dummy variable that takes on a value of 1 from 2000 to 2010 and 0 at any other time; and $\operatorname{Lac} D_{i} \cdot \operatorname{Boom} D_{t}$ is a dummy variable that takes on a value of 1 only for LAC countries during the commodity boom period (2000-2010) and a value of 0 for non-LAC countries. The interaction terms $\left(\beta_{7} k_{i t}+\beta_{8} a x_{i t}+\beta_{9} t p_{i t}\right)$. Boom $D_{t}$ and $\left(\beta_{10} k_{i t}+\beta_{11} a x_{i t}+\beta_{12} t p_{i t}\right) \cdot \operatorname{Lac} D_{i} \cdot \operatorname{Boom} D_{t}$ are included to assess the channel through which the export boom affected growth for the entire group of countries, as well as for LAC countries.

In our third set of models, where we test for the effect of specific types of exports on growth, we run separate analyses for four commodity groups (agricultural raw materials exports, ore and minerals exports, food exports, and fuel exports) and for manufactured exports, all measured as a percentage of merchandise exports for each country. This disaggregation is taken from the classification by the World Bank in the WDI database. In these analyses, we include $\operatorname{Boom} D_{t}$ and $\operatorname{Lac} D_{i} \cdot \operatorname{Boom} D_{t}$ variables as well as three new variables to include the impact of each specific export type for each country on the GDP per capita growth. Comm $D_{i j}$ is a variable where $j$ stands for agriculture exports, food exports, fuel exports, ore and mineral exports or manufactured exports. $\operatorname{Comm} D_{j i} \cdot \operatorname{Boom} D_{t}$ represents exports of each export category $j$ during the boom period for each country, while $\operatorname{Lac} D_{i} \cdot \operatorname{Comm} D_{j i}$. Boom $_{t}$ represents exports of each export category during the boom period only for LAC countries. This model is presented in the Eq. 4. 


$$
\begin{aligned}
y_{i t}= & \alpha+\beta_{0} Y_{i, o}+\beta_{1}+\beta_{2} k_{i t}+\beta_{3} a x_{i t}+\beta_{4} t p_{i t}+\beta_{5} \operatorname{Boom} D_{t}+\beta_{6} \operatorname{Lac} D_{i} \cdot \operatorname{Boom} D_{t} \\
& +\left(\beta_{7} k_{i t}+\beta_{8} a x_{i t}+\beta_{9} t p_{i t}\right) \cdot \operatorname{Boom} D_{t}+\left(\beta_{10} k_{i t}+\beta_{11} a x_{i t}+\beta_{12} t p_{i t}\right) \cdot \operatorname{Lac} D_{i} \cdot \operatorname{Boom} D_{t} \\
& +\beta_{15 j} \cdot \operatorname{Comm} D_{j i}+\beta_{16 j} \cdot \operatorname{Comm} D_{j i} \cdot \operatorname{Boom} D_{t} \\
& +\beta_{17 j} \cdot \operatorname{Comm} D_{j i} \cdot \operatorname{Lac}_{i} \cdot \operatorname{Boom}_{t}+\sum_{k=-1}^{1} \gamma_{k} \Delta a x_{i t}+\varepsilon_{i t} .
\end{aligned}
$$

Most of the data were obtained from the World Bank's World Development Indicators (WDI) (World Bank 2012) for the period 1990-2010 for 97 countries, 14 of which are LAC countries. The WDI variables for each country are real GDP per capita growth (annual \%); real GDP per capita in 1990; gross capital formation (annual \% growth); exports of goods and services (annual \% growth); and agricultural raw materials exports, food exports, fuel exports, ore and mineral exports and manufactured exports (each as \% of merchandise exports). Exports by trade partners are from the IMF's direction of trade statistics (DoTS). Exports by trade partners were used to compute the weighted trade partner growth as described in Beny and Cook (2009). From the matrix of exports by trade partner a weighted matrix was obtained, which was multiplied by the GDP growth of each trade partner, giving a matrix of weighted partner growth for each country in each time period.

From the descriptive statistics shown in Table 1, it can be observed that during the entire period the yearly average GDP per capita growth of all the countries under study was $2.45 \%$, and a clear difference existed between the period 1990-1999 and

\begin{tabular}{|c|c|c|c|c|c|}
\hline \multirow[t]{2}{*}{ Variable } & \multicolumn{2}{|c|}{ LAC countries } & \multicolumn{2}{|c|}{ Non-LAC countries } & \multirow{2}{*}{$\begin{array}{l}\text { All } \\
\text { countries } \\
\text { 1990-2010 }\end{array}$} \\
\hline & 1990-1999 & 2000-2010 & 1990-1999 & $2000-2010$ & \\
\hline GDP per capita real growth & $2.07 \%$ & $2.56 \%$ & $2.19 \%$ & $2.72 \%$ & $2.45 \%$ \\
\hline Capital formation annual growth & $8.13 \%$ & $6.01 \%$ & $4.91 \%$ & $5.59 \%$ & $5.62 \%$ \\
\hline Trade partner annual growth & $2.09 \%$ & $8.88 \%$ & $2.74 \%$ & $8.51 \%$ & $5.71 \%$ \\
\hline Exports annual growth & $7.42 \%$ & $4.81 \%$ & $7.44 \%$ & $6.58 \%$ & $6.87 \%$ \\
\hline $\begin{array}{l}\text { Agricultural raw materials exports } \\
\text { (\% of merchandise exports) }\end{array}$ & $4.70 \%$ & $3.03 \%$ & $5.09 \%$ & $4.61 \%$ & $4.71 \%$ \\
\hline $\begin{array}{l}\text { Fuel exports (\% of merchandise } \\
\text { exports) }\end{array}$ & $17.19 \%$ & $21.99 \%$ & $9.92 \%$ & $13.08 \%$ & $12.89 \%$ \\
\hline $\begin{array}{l}\text { Food exports (\% of merchandise } \\
\text { exports) }\end{array}$ & $30.36 \%$ & $23.97 \%$ & $18.49 \%$ & $14.48 \%$ & $18.11 \%$ \\
\hline $\begin{array}{l}\text { Ores and metals exports (\% of } \\
\text { merchandise exports) }\end{array}$ & $11.92 \%$ & $12.48 \%$ & $5.00 \%$ & $6.06 \%$ & $6.63 \%$ \\
\hline $\begin{array}{l}\text { Manufactured exports (\% of } \\
\text { merchandise exports) }\end{array}$ & $33.89 \%$ & $37.85 \%$ & $59.75 \%$ & $59.01 \%$ & $55.53 \%$ \\
\hline
\end{tabular}
the period related to the commodities boom (2000-2010) for both LAC and nonLAC countries. In the case of non-LAC countries, their growth rate increased from

Table 1 Descriptive statistics: mean of the economic variables 
2.19 to $2.72 \%$ during the commodities boom; for LAC countries this increment was lower, from 2.07 to $2.56 \%$.

Annual growth of capital formation for LAC countries was $8.13 \%$ during 1990-199 but fell to 6.01\% during 2000-2010; capital formation was $4.91 \%$ for non-LAC countries during 1990-1999 and rose to 5.59 \% during 2000-2010. For non-LAC countries in the period 1990-1999 export trade partners' average growth was $2.74 \%$, while for the LAC countries it was $2.09 \%$, but during the period 2000-2010 the trade partners' growth increased more for LAC countries than nonLAC countries, reaching a slightly higher rate; LAC countries' trade partners had an average growth of $8.88 \%$ and non-LAC countries, $8.51 \%$. The annual growth of exports decreased on average in the boom period for all countries in study, but LAC countries experienced a decline of $2.61 \%$ points while non-LAC countries experienced a decline of only $0.86 \%$ points. The sums of the merchandise export shares shown in Table 1 do not sum to $100 \%$ because of unclassified trade.

\section{Results and discussion}

All the models are estimated through dynamic ordinary least squares (DOLS) using the white cross-sectional standard error and covariance method, to eliminate the endogeneity (Herzer and Vollmer 2012) and to obtain comparable results between models with and without dummy variables (Wooldridge 2002). The results of model 1 (Eq. 2), the ELG model (see Table 2) show that capital formation, export growth, and trade partner growth had a positive and statistically significant effect on GDP per capita growth, with estimators of $0.118,0.192$, and $0.040 \%$ points, respectively. The coefficient for the 1990 level of GDP per capita is positive in contrast to the predicted negative value but is not statistically significant.

The analysis of model 2 (Eq. 3) shows that capital formation and export growth are consistent with the results in model 1, but trade partner growth loses its statistical significance; instead the interaction between trade partner growth and "Boom" has a significant coefficient of 0.069, indicating that this effect is concentrated during the commodity boom period. In the case of LAC countries and for all countries during the commodity boom period, there is no additional statistical significance for ELG variables. In model 2, the 1990 level of GDP per capita shows a positive effect with weak statistical significance; thus the assumption of faster growth for countries with lower initial levels of GDP per capita is not supported.

Summarizing the results above, capital formation and export growth appear to have a positive effect on growth over the entire time period while trade partner growth arises as a globally important factor during the boom period.

In Table 3, we study the commodity boom effects on GDP per capita growth in LAC versus non-LAC countries for specific export groups (Eq. 4); the variables for the export groups are the four commodity groups (agricultural raw materials exports, ore and mineral exports, food exports, and fuel exports), each as a percentage of total merchandise exports. Also, we include manufactured exports for comparison purposes. 
Table 2 GDP per capita growth models with commodity boom and LAC dummy variables

\begin{tabular}{lll}
\hline Variables & Model 1 & Model 2 \\
\hline Constant & -0.925131 & -1.092738 \\
Capital formation & $0.117678^{* * *}$ & $0.131329^{* * *}$ \\
Export growth & $0.191744^{* * *}$ & $0.182029^{* * *}$ \\
Trade partner growth & $0.039590^{* *}$ & -0.009106 \\
GDP 1990 & 0.128278 & $0.120940^{*}$ \\
Boom comm. period dummy & & 0.311355 \\
LAC $\times$ boom & & 0.120653 \\
Capital formation $\times$ boom & & -0.034052 \\
Export growth $\times$ boom & & 0.032670 \\
Trade partner growth $\times$ boom & & $0.069926^{* * *}$ \\
Capital formation $\times$ LAC $\times$ boom & & 0.014045 \\
Export growth $\times$ LAC $\times$ boom & & 0.023272 \\
Trade partner growth $\times$ LAC $\times$ boom & & -0.009656 \\
D export growth & & $-0.071610^{* * *}$ \\
D export growth $T+1$ & $-0.070381^{* * *}$ & 0.015441 \\
$D$ export growth $T-1$ & 0.011529 & $-0.047712^{* * *}$ \\
$R^{2}$ & $-0.049450^{* * *}$ & 0.468630 \\
Adjusted $R^{2}$ & 0.449815 & 0.463982 \\
Log likelihood & 0.447580 & -4283.711 \\
$F$-statistic & -4313.826 & 100.8336 \\
Prob $F$-statistic $)$ & 201.2395 & 0.000000 \\
Akaike info criterion & 0.000000 & 4.967892 \\
Schwarz criterion & 4.993444 & 5.018327 \\
Hannan-Quinn criter. & 5.018661 & 4.986547 \\
Durbin-Watson stat & 5.002771 & 1.241018 \\
\hline
\end{tabular}

***,**,* Mean statistical significance at 1,5 and $10 \%$

For the five equations in Table 3, capital formation and export growth continue to show positive effects on economic growth, supporting ELG hypothesis. During boom period, export growth and trade partner growth show additional positive effects on economic growth, which supports the ELG hypothesis and suggests that during this period, commercial interactions between countries lead to synergic effects. No additional statistically significant effects for the ELG variables are found during boom period for LAC countries.

Model "Ore" shows that ore and mineral exports, in general, had a negative effect on GDP per capita growth for all countries over the entire period. But ore and mineral exports had a positive impact of $0.027 \%$ points for LAC countries during the boom period. In the case of agricultural raw material products, the effect is negative for all countries during the boom period $(-0.028)$ and is even more negative for LAC countries during the boom period (-0.143). Fuel exports have a negative effect on the GDP per capita growth, but a slightly positive effect during the boom period for all countries. Food exports have a generally negative effect for 
Table 3 GDP per capita growth models with commodity boom and Latin American dummies and breakdown of commodity exports

\begin{tabular}{|c|c|c|c|c|c|}
\hline Variables & Model ore & Model agri & Model fuel & Model food & $\begin{array}{l}\text { Model } \\
\text { manu }\end{array}$ \\
\hline Constant & 0.5207 & 0.2199 & 0.3791 & $1.3822 *$ & 0.3157 \\
\hline Capital formation & $0.1238 * * *$ & $0.1226 * * *$ & $0.1239 * * *$ & $0.1231 * * *$ & $0.1251 * * *$ \\
\hline Export growth & $0.1493 * * *$ & $0.1515 * * *$ & $0.1520 * * *$ & $0.1446 * * *$ & $0.1391 * * *$ \\
\hline Trade partner growth & -0.0061 & -0.0055 & -0.0078 & -0.0035 & -0.0077 \\
\hline GDP 1990 & 0.0092 & 0.0157 & 0.0251 & -0.0681 & $-0.1237 *$ \\
\hline Boom comm. period dummy & -0.0395 & 0.1728 & -0.1946 & 0.1026 & 0.2171 \\
\hline LAC $\times$ boom & -0.3265 & 0.3340 & -0.2970 & 0.1358 & 0.8854 \\
\hline Capital formation $\times$ boom & -0.0228 & -0.0220 & -0.0251 & -0.0243 & -0.0232 \\
\hline Export growth $\times$ boom & $0.0433 * *$ & $0.0420 * *$ & $0.0432 * *$ & $0.0426 * *$ & $0.0389 * *$ \\
\hline $\begin{array}{l}\text { Trade partner } \\
\text { growth } \times \text { boom }\end{array}$ & $0.0599 * * *$ & $0.0594 * * *$ & $0.0610 * * *$ & $0.0572 * * *$ & $0.0606^{* * *}$ \\
\hline $\begin{array}{l}\text { Capital } \\
\text { formation } \times \text { LAC } \times \text { boom }\end{array}$ & 0.0078 & 0.0076 & 0.0086 & 0.0085 & 0.0075 \\
\hline $\begin{array}{l}\text { Export } \\
\text { growth } \times \text { LAC } \times \text { boom }\end{array}$ & 0.0272 & 0.0317 & 0.0320 & 0.0363 & 0.0351 \\
\hline $\begin{array}{l}\text { Trade partner } \\
\text { growth } \times \text { LAC } \times \text { boom }\end{array}$ & 0.0009 & -0.0046 & -0.0010 & -0.0054 & 0.0006 \\
\hline DEXPO_? & $-0.0533 * * *$ & $-0.0534 * * *$ & $-0.0548 * * *$ & $-0.0506^{* * *}$ & $-0.0482 * * *$ \\
\hline DEXPO_?(1) & 0.0114 & 0.0127 & 0.0120 & 0.0106 & 0.0077 \\
\hline DEXPO_?(-1) & $-0.0307 * * *$ & $-0.0303 * * *$ & $-0.0311 * * *$ & $-0.0289 * * *$ & $-0.0277 * * *$ \\
\hline Ore and mineral exports & $-0.0297 * * *$ & & & & \\
\hline $\begin{array}{l}\text { Ore and mineral } \\
\text { exports } \times \text { boom }\end{array}$ & 0.0095 & & & & \\
\hline $\begin{array}{l}\text { Ore and mineral } \\
\text { exports } \times \text { boom } \times \text { LAC }\end{array}$ & $0.0276^{* *}$ & & & & \\
\hline Agricultural raw mat. exports & & 0.0080 & & & \\
\hline $\begin{array}{l}\text { Agricultural raw mat. } \\
\text { exports } \times \text { boom }\end{array}$ & & $-0.0283^{* *}$ & & & \\
\hline $\begin{array}{l}\text { Agricultural raw mat. } \\
\text { exports } \times \text { boom } \times \text { LAC }\end{array}$ & & $-0.1437 * *$ & & & \\
\hline Fuel exports & & & $-0.0159 * * *$ & & \\
\hline Fuel exports $\times$ boom & & & $0.0179 * * *$ & & \\
\hline $\begin{array}{l}\text { Fuel } \\
\text { exports } \times \text { boom } \times \text { LAC }\end{array}$ & & & 0.0085 & & \\
\hline Food exports & & & & $-0.0180^{* * *} *$ & \\
\hline Food exports $\times$ boom & & & & $-0.0110^{*}$ & \\
\hline $\begin{array}{l}\text { Food } \\
\text { exports } \times \text { boom } \times \text { LAC }\end{array}$ & & & & -0.0003 & \\
\hline Manufactured exports & & & & & $0.0220 * * *$ \\
\hline $\begin{array}{l}\text { Manufactured } \\
\text { exports } \times \text { boom }\end{array}$ & & & & & -0.0043 \\
\hline $\begin{array}{l}\text { Manufactured } \\
\text { exports } \times \text { boom } \times \text { LAC }\end{array}$ & & & & & $-0.0194 * * *$ \\
\hline
\end{tabular}


Table 3 continued

\begin{tabular}{llllll}
\hline Variables & Model ore & Model agri & Model fuel & Model food & $\begin{array}{l}\text { Model } \\
\text { manu }\end{array}$ \\
\hline$R^{2}$ & 0.4596 & 0.4568 & 0.4600 & 0.4656 & 0.4716 \\
Adjusted $R^{2}$ & 0.4535 & 0.4507 & 0.4539 & 0.4594 & 0.4656 \\
Log likelihood & -3856 & -3868 & -3843 & -3855 & -3846 \\
$F$-statistic & 74.79 & 74.15 & 74.77 & 76.79 & 78.69 \\
Prob $(F$-statistic) & 0.0000 & 0.0000 & 0.0000 & 0.0000 & 0.0000 \\
Akaike info criterion & 4.8383 & 4.8410 & 4.8312 & 4.8249 & 4.8134 \\
Schwarz criterion & 4.9021 & 4.9046 & 4.8950 & 4.8885 & 4.8771 \\
Hannan-Quinn criter. & 4.8619 & 4.8646 & 4.8549 & 4.8485 & 4.8370 \\
Durbin-Watson stat & 1.2698 & 1.2537 & 1.2679 & 1.2744 & 1.2968 \\
\hline
\end{tabular}

$* * *, * *, *$ Mean statistical significance at 1,5 and $10 \%$

the entire period of the study, and a greater negative effect during the boom period. Manufactured exports generally had a positive impact on the GDP per capita growth (0.022), but the coefficient for their effect on LAC countries during the boom period is negative, indicating manufactured exports of LAC countries had very little positive effect on growth during the commodity boom.

The above analysis looks at the aggregate effects of various export groups on LAC countries during the boom. It shows that only ore and mineral exports increased the growth of LAC countries during the boom period. If we look at individual LAC countries having large ore and mineral exports or large fuel exports, we see that the contribution of these commodity exports to growth was substantial during the boom. According to our results, during the 2000-2010 boom period, the share of ores and minerals in exports explained 14.1\% of GDP per capita growth for Chile, $9.4 \%$ for Bolivia, and $8.4 \%$ for Peru. The share of fuel exports explained $49.8 \%$ of GDP per capita growth for Venezuela, $21.2 \%$ for Bolivia, $17.6 \%$ for Colombia, $12.8 \%$ for Argentina, and $14.2 \%$ for Mexico.

\section{Concluding remarks}

The results show that, in general, during the period of 2000-2010 corresponding to commodity boom GDP per capita growth was $24 \%$ higher than in 1990-1999 on average for the non-LAC countries and also $24 \%$ higher for the LAC countries. Our first model, which looks at all countries over the entire period, supports the ELG theory. Growth of GDP per capita is a function of capital formation, export growth and trade partner growth. Our second model is similar except that trade partner growth is significant only during the boom period. The third set of models has similar results supporting the ELG theory, but indicates that the type of exports can have effects on growth that vary between the boom and non-boom period, and between LAC and non-LAC countries. To summarize, ore and mineral exports generally have negative effects on growth but not for LAC countries during the 
boom. Agricultural exports generally have negative effects only during the boom and then especially on LAC countries. Fuel exports have a negative effect in the non-boom period but not during the boom. Food exports have a negative effect on growth during the entire period, and slightly more negative during the boom period. On the other hand, manufactured exports generally have a positive effect on growth over the period examined, except for LAC countries during the boom. When we look at individual LAC countries, we can see that growth of major ore and mineral exporters and major fuel exporters was significantly impacted by the commodity boom. Therefore, we can expect that the end of the commodity boom took its toll on these LAC countries.

Open Access This article is distributed under the terms of the Creative Commons Attribution 4.0 International License (http://creativecommons.org/licenses/by/4.0/), which permits unrestricted use, distribution, and reproduction in any medium, provided you give appropriate credit to the original author(s) and the source, provide a link to the Creative Commons license, and indicate if changes were made.

\section{Appendix: chow breakpoint test for the commodities indexes}

\begin{tabular}{lrccr}
\hline & $F$-statistic & $p$ value & Wald statistic & $p$ value \\
\hline PRAWM index & 3.5109 & 0.0529 & 7.0218 & 0.0299 \\
PMETA index & 14.6566 & 0.0002 & 29.3133 & 0.0000 \\
POILAPSP index & 9.7403 & 0.0015 & 19.4806 & 0.0001 \\
\hline
\end{tabular}

Chow breakpoint test applied to each series (1990-2000) and (2001-2010) for the year 2000 in the equation with intercept and trend

\section{References}

Addison T, Ghoshray A, Stamatogiannis MP (2016) Agricultural commodity price shocks and their effect on growth in Sub-Saharan Africa. J Agric Econ 67:47-61

Al-Marhubi F (2000) Export diversification and growth: an empirical investigation. Appl Econ Lett 7:559-562

Arora V, Vamvakidis A (2005a) How much do trading partners matter for economic growth? IMF Staff Pap 52:24-40

Arora V, Vamvakidis A (2005b) The implications of South African economic growth for the rest of Africa. S Afr J Econ 73:229-242

Barro RJ (1991) Economic growth in a cross section of countries. Q J Econ 106:407-443

Beny L, Cook L (2009) Metals or management? Explaining Africa's recent economic growth performance. Am Econ Rev 99:268-274

Camacho M, Perez-Quiros G (2014) Commodity prices and the business cycle in Latin America: living and dying by commodities? Emerg Mark Financ Trade 50:110-137

Cavalcanti DV, Tiago V, Mohaddes K, Raissi M (2015) Commodity price volatility and the sources of growth. J Appl Econ 30:857-873

Collier P, Goderis B (2012) Commodity prices and growth: an empirical investigation. Eur Econ Rev 56:1241-1260 
Dabla-Norris E, Espinoza R, Jahan S (2015) Spillovers to low-income countries: importance of systemic emerging markets. Appl Econ 47:5707-5725

DeJong D, Whiteman C (1991) The case for trend-stationarity is stronger than we thought. J Appl Econ 6:413-421

Dijkstra A (2000) Trade liberalization and industrial development in Latin-America. World Dev 28:1567-1582

Dreger C, Herzer D (2013) A further examination of the export-led growth hypothesis. Empir Econ 45:39-60

Fagiolo G, Reyes J, Schiavo S (2010) The evolutions of the world trade web: a weighted-network analysis. J Evol Econ 20:479-514

Feder G (1982) On exports and economic growth. J Dev Econ 12:59-93

Giles J, Williams C (2000a) Export-led growth: a survey of the empirical literature and some noncausality results. Part 1. J Int Trade Econ Dev 9:261-337

Giles J, Williams C (2000b) Export-led growth: a survey of the empirical literature and some noncausality results. Part 2. J Int Trade Econ Dev 9:445-470

Greenaway D, Morgan W, Wright P (1999) Exports, export composition and growth. J Int Trade Econ Dev 8:41-51

Gruss B (2014) After the boom-commodity prices and economic growth in Latin America and the Caribbean. IMF Working Paper WP/14/154

Herzer D, Vollmer S (2012) Inequality and growth: evidence from panel cointegration. J Econ Inequal 10:489-503

Humphreys D (2010) The great metals boom: a retrospective. Resour Policy 35:1-13

Kali R, Méndez F, Reyes J (2007) Trade structure and economic growth. J Int Trade Econ Dev 16:245-269

Leybourne S (1995) Testing for unit roots using forward and reverse Dickey-Fuller regressions. Oxf Bull Econ Stat 57:559-571

Mookerjee R (2006) A meta-analysis of the export growth hypothesis. Econ Lett 91:395-401

Sachs JD, Warner AM (1995) Natural resource abundance and economic growth. NBER Working Paper Series, Working Paper 5398

Sannassee R, Seetanah B, Jugessur J (2014) Export-led growth hypothesis: a meta-analysis. J Dev Areas 48:361-385

Siliverstovs B, Herzer D (2006) Export-led growth hypothesis: evidence for Chile. Appl Econ Lett 13:319-324

Spatafora N, Tytell I (2009) Commodity terms of trade: the history of booms and busts. IMF Working Paper WP/09/205

Sprout RVA, Weaver JH (1993) Exports and economic growth in a simultaneous equation model. J Dev reas 27:289-306

Wooldridge JM (2002) Econometric analysis of cross section and panel data. MIT press, Cambridge

World Bank (2012) World development indicators. World Bank, Washington 